\title{
Do Practice Patterns Reflect Practice Guidelines?
}

\author{
Tina W. F. Yen, MD, MS and Douglas B. Evans, MD \\ Division of Surgical Oncology, Department of Surgery, Medical College of Wisconsin, Milwaukee, WI
}

The emergence of clinical practice guidelines and consensus statements has stimulated a critical review of the literature and healthy debate among experts regarding how and when to treat patients with various diseases, especially cancer. An article in this issue of Annals of Surgical Oncology by Panigrahi and colleagues comments on the recent medullary thyroid cancer (MTC) guidelines published by the American Thyroid Association. ${ }^{1,2}$ In using the Surveillance, Epidemiology, and End Results Program (SEER) database, these investigators found that a high number of patients with MTC, treated from 1988 to 2006, received treatment viewed as out of line with the 2009 American Thyroid Association guidelines. Although this may well be true, there are limitations to the conclusions which one can draw from an analysis of such large data repositories. The SEER database and other tumor registries are intended primarily as sources of cancer incidence and mortality rates. ${ }^{3}$ Information regarding initial treatment is recorded, but follow-up data (except for date and cause of death) such as locoregional recurrences, distant metastases, and subsequent treatments are not routinely collected. Advantages of SEER are as follows: it includes data from large cohorts; it is population-based; it represents all age groups; and it has a wide geographic range, thereby decreasing selection biases that may hamper clinical trials and studies that are based on institutional databases. Information on stage of disease and initial treatment are verified for accuracy; however, specific details regarding the disease and surgical treatment (such as RET mutation status, the exact location of nodal disease, the specific type of neck dissection and completeness of resection), which are typically recorded in institutional, organ-specific databases and clinical trials, may not be included in SEER.

(C) Society of Surgical Oncology 2010

Published Online: 16 March 2010

D. B. Evans, MD

e-mail: devans@mcw.edu
The lack of organ-specific details and information on comorbid illnesses and other diagnoses restrict the analyses and conclusions that can be drawn from such large tumor registries. Despite these limitations, one important reason to study population-based registries is that it allows us to examine the management and true effectiveness of therapies performed in the real world, rather than in the tightly controlled settings of clinical trials and high-volume referral centers. Although the use of these large tumor registries and administrative databases (such as Medicare and the Healthcare Costs and Utilization Project) to study patterns of cancer treatment has increased dramatically, one must be aware of the limitations of each database in all aspects of research design (hypothesis generation), data analysis and interpretation, and perhaps most importantly, the development of conclusions and recommendations. ${ }^{4,5}$

Importantly, Panigrahi and colleagues emphasized the use of guidelines in standardizing the quality and cost of cancer treatment. There is no doubt that we are now in an era of evidence-based medicine where clinical pathways and treatment guidelines are quoted on a daily basis, especially in academic medical centers. For subspecialists and multidisciplinary working groups who manage high volumes of patients with, for example, thyroid cancer, such guidelines may streamline the diagnostic evaluation and treatment, provide consensus on stage-specific therapies, and minimize cost by avoiding unnecessary testing. In the perioperative period, clinical pathways will avoid unnecessary laboratory tests and/or radiographs and provide a foundation for teaching trainees how to care for patients, some of whom may have rare (sporadic or inherited) diseases such as MTC. In contrast, such pathways and guidelines may discourage the development of independent thinking which is necessary to mature as a physician, especially when residents may be desperately trying to adhere to work hour regulations. In addition, to what degree do defined treatment guidelines prevent the needed dialog regarding both complex and simple clinical 
questions, which is often necessary for the training of medical students and residents? Our challenge as educators is not only to incorporate such valuable information into both organized curriculum and daily bedside teaching, but also to constantly question and challenge these guidelines to further advance our understanding of these complex disease processes.

For those physicians already in practice, the recent publication of guidelines and consensus conferences has raised the bar with respect to expectations for clinical care, especially in oncology. A number of cooperative groups and international societies have published guidelines and consensus conference statements to improve the care of patients with cancer. Table 1 lists a number of guidelines and consensus statements published for thyroid, breast, and pancreatic cancer (our areas of concentration). The presence of these documents sets a standard (in some cases, a standard with obvious legal implications) for patient care that can only be met if this large body of literature is acknowledged and widely adopted. For those surgeons whose practice is not limited to a relatively narrow subspecialty, staying up to date and knowledgeable regarding

TABLE 1 Published guidelines and consensus statements (thyroid, breast, pancreas)

\begin{tabular}{|c|c|c|}
\hline Organization & Publication & Year/Study \\
\hline \multicolumn{3}{|l|}{ Thyroid } \\
\hline $\begin{array}{l}\text { American Thyroid } \\
\text { Association (ATA) }\end{array}$ & $\begin{array}{l}\text { Medullary Thyroid Cancer: Management Guidelines of the American } \\
\text { Thyroid Association }\end{array}$ & $2009 /^{2}$ \\
\hline ATA & $\begin{array}{l}\text { Revised American Thyroid Association Management Guidelines for } \\
\text { Patients with Thyroid Nodules and Differentiated Thyroid Cancer }\end{array}$ & $2009 /^{6}$ \\
\hline ATA & $\begin{array}{l}\text { Consensus Statement on the Terminology and Classification of } \\
\text { Central Neck Dissection for Thyroid Cancer }\end{array}$ & $2009 /^{7}$ \\
\hline $\begin{array}{l}\text { National Comprehensive } \\
\text { Cancer Network (NCCN) }\end{array}$ & Clinical Practice Guidelines in Oncology: Thyroid Carcinoma & $2010 /^{8}$ \\
\hline \multicolumn{3}{|l|}{ Breast } \\
\hline $\begin{array}{l}\text { American Society of } \\
\text { Clinical Oncology } \\
\text { (ASCO) }\end{array}$ & $\begin{array}{l}\text { American Society of Clinical Oncology technology assessment on the } \\
\text { use of aromatase inhibitors as adjuvant therapy for postmenopausal } \\
\text { women with hormone receptor-positive breast cancer: status report } \\
2004\end{array}$ & $2004 /^{9}$ \\
\hline ASCO & $\begin{array}{l}\text { American Society of Clinical Oncology guideline recommendations } \\
\text { for sentinel lymph node biopsy in early-stage breast cancer }\end{array}$ & $2005 /^{10}$ \\
\hline ASCO & $\begin{array}{l}\text { American Society of Clinical Oncology } 2006 \text { update of the breast } \\
\text { cancer follow-up and management guidelines in the adjuvant } \\
\text { setting }\end{array}$ & $2006 / /^{11}$ \\
\hline ASCO & $\begin{array}{l}\text { American Society of Clinical Oncology } 2007 \text { update of } \\
\text { recommendations for the use of tumor markers in breast cancer }\end{array}$ & $2007 / /^{12}$ \\
\hline ASCO & $\begin{array}{l}\text { American Society of Clinical Oncology/College of American } \\
\text { Pathologists guideline recommendations for human epidermal } \\
\text { growth factor receptor } 2 \text { testing in breast cancer }\end{array}$ & $2007 /^{13}$ \\
\hline $\begin{array}{l}\text { European Society of } \\
\text { Medical Oncology } \\
\text { (ESMO) }\end{array}$ & $\begin{array}{l}\text { ESMO Minimum Clinical Recommendations for diagnosis, adjuvant } \\
\text { treatment and follow-up of primary breast cancer }\end{array}$ & $2005 /^{14}$ \\
\hline NCCN & Clinical Practice Guidelines in Oncology: Breast Cancer & $2010 /{ }^{15}$ \\
\hline $\begin{array}{l}\text { St. Gallen International } \\
\text { Consensus Panel }\end{array}$ & $\begin{array}{l}\text { Meeting Highlights: International Expert Consensus on Primary } \\
\text { Therapy of Early Breast Cancer } 2005\end{array}$ & $2005 /^{16}$ \\
\hline \multicolumn{3}{|l|}{ Pancreas } \\
\hline $\mathrm{NCCN}$ & Clinical Practice Guidelines in Oncology: Pancreatic Adenocarcinoma & $2009 / 1^{17}$ \\
\hline AHPBA/SSAT/SSO ${ }^{\mathrm{a}}$ & $\begin{array}{l}\text { Surgical Treatment of Resectable and Borderline Resectable Pancreas } \\
\text { Cancer: Expert Consensus Statement }\end{array}$ & $2009 /^{18}$ \\
\hline AHPBA/SSAT/SSO ${ }^{\mathrm{a}}$ & $\begin{array}{l}\text { Combined Modality Treatment of Resectable and Borderline } \\
\text { Resectable Pancreas Cancer: Expert Consensus Statement }\end{array}$ & $2009 / /^{19}$ \\
\hline $\begin{array}{l}\text { International Association } \\
\text { of Pancreatology }\end{array}$ & $\begin{array}{l}\text { International Consensus Guide for Management of Intraductal } \\
\text { Papillary Mucinous Neoplasms and Mucinous Cystic Neoplasms of } \\
\text { the Pancreas }\end{array}$ & $2006 / 2^{20}$ \\
\hline NCCN & Clinical Practice Guidelines in Oncology: Neuroendocrine tumors & $2009 /^{21}$ \\
\hline
\end{tabular}

${ }^{a}$ American Hepato-Pancreato-Biliary Association/Society of Surgery for the Alimentary Tract/Society of Surgical Oncology 
treatment guidelines and consensus statements is indeed a challenge. Therein lies the importance of emphasizing such information to medical students and residents early on in their career. The eventual incorporation of such information into the electronic medical record is already underway. Similar to the use of smart phrases, such guidelines can be made available by the click of the mouse when the specific cancer diagnosis is selected in the initial history and physical or in a consultation note. Will this prevent an excisional biopsy of a lateral neck lymph node in a patient with papillary thyroid cancer (rather than a fine-needle aspiration biopsy followed by compartment-oriented dissection), the failure to perform a central compartment dissection in a patient with MTC, or a laparotomy for an obviously unresectable pancreatic cancer? For now, it is critically important that all physicians and surgeons who care for patients with cancer be aware of the availability of management and treatment guidelines and consensus statements and refer to them frequently. The 2009 American Thyroid Association Medullary Thyroid Cancer Guidelines represent a distillation of a detailed analysis of data and discussion by a team of multidisciplinary experts; we hope that such information will positively influence the management of future patients with MTC.

\section{REFERENCES}

1. Panigrahi B, Roman SA, Sosa JA. Medullary thyroid cancer: are practice patterns in the United States discordant from American Thyroid Association guidelines? Ann Surg Oncol. doi:10.1245/s 10434-010-1017-0.

2. Kloos RT, Eng C, Evans DB, et al. Medullary thyroid cancer: management guidelines of the American Thyroid Association. Thyroid. 2009;19:565-612.

3. Surveillance Epidemiology and End Results. Overview of the SEER program. http://www.seer.cancer.gov. Accessed February 2010.

4. Centers for Medicare and Medicaid Services. Research, statistics, data and systems. http://www.cms.hhs.gov/home/rsds.asp. Accessed February 2010.

5. Healthcare Cost and Utilization Project (HCUP). http://www. hcup-us.ahrq.gov. Accessed February 2010.

6. Cooper DS, Doherty GM, Haugen BR, et al. Revised American Thyroid Association management guidelines for patients with thyroid nodules and differentiated thyroid cancer. Thyroid. 2009;19:1-48.

7. Carty SE, Cooper DS, Doherty GM, et al. Consensus statement on the terminology and classification of central neck dissection for thyroid cancer. Thyroid. 2009;19:1153-9.
8. National Comprehensive Cancer Network. Clinical practice guidelines for medullary thyroid carcinoma. 2010. http://www. nccn.org/professionals/physician_gls/f_guidelines.asp. Accessed February 2010.

9. Winer EP, Hudis C, Burstein HJ, et al. American Society of Clinical Oncology technology assessment on the use of aromatase inhibitors as adjuvant therapy for postmenopausal women with hormone receptor-positive breast cancer: status report 2004. J Clin Oncol. 2005;23:619-29.

10. Lyman GH, Giuliano AE, Somerfield MR, et al. American Society of Clinical Oncology guideline recommendations for sentinel lymph node biopsy in early-stage breast cancer. J Clin Oncol. 2005;23:7703-20.

11. Khatcheressian JL, Wolff AC, Smith TJ, et al. American Society of Clinical Oncology 2006 update of the breast cancer follow-up and management guidelines in the adjuvant setting. J Clin Oncol. 2006;24:5091-7.

12. Harris L, Fritsche H, Mennel R, et al. American Society of Clinical Oncology 2007 update of recommendations for the use of tumor markers in breast cancer. J Clin Oncol. 2007;25:5287312.

13. Wolff AC, Hammond ME, Schwartz JN, et al. American Society of Clinical Oncology/College of American Pathologists guideline recommendations for human epidermal growth factor receptor 2 testing in breast cancer. J Clin Oncol. 2007;25:118-45.

14. Pestalozzi BC, Luporsi-Gely E, Jost LM, Bergh J. ESMO minimum clinical recommendations for diagnosis, adjuvant treatment and follow-up of primary breast cancer. Ann Oncol. 2005;16 (Suppl 1):i7-9.

15. National Comprehensive Cancer Network. Clinical practice guidelines for breast cancer. 2010. http://www.nccn.org/ professionals/physician_gls/f_guidelines.asp. Accessed February 2010.

16. Goldhirsch A, Glick JH, Gelber RD, et al. Meeting highlights: international expert consensus on the primary therapy of early breast cancer 2005. Ann Oncol. 2005;16:1569-83.

17. National Comprehensive Cancer Network. Pancreatic adenocarcinoma. 2009. http://www.nccn.org/professionals/physician_gls/ f_guidelines.asp. Accessed February 2010.

18. Evans DB, Farnell MB, Lillimoe KD, et al. Surgical treatment of resectable and borderline resectable pancreas cancer: expert consensus statement. Ann Surg Oncol. 2009;16:1736-44.

19. Abrams RA, Lowy AM, O'Reilly EM, et al. Combined modality treatment of resectable and borderline resectable pancreas cancer: expert consensus statement. Ann Surg Oncol. 2009;16:1751-6.

20. Tanaka M, Chari S, Adsay V, et al. International consensus guide for management of intraductal papillary mucinous neoplasms and mucinous cystic neoplasms of the pancreas. Pancreatology. 2006;6:17-32.

21. National Comprehensive Cancer Network. Neuroendocrine tumors. 2009. http://www.nccn.org/professionals/physician_gls/ f_guidelines.asp. Accessed February 2010. 